\title{
Effect of higher salinities on growth and survival of pacific white shrimp, Litopenaeus vannamei (Boone, 1931)
}

\author{
M. Ayaz, K. Sumara*, Kailash H. Vadher and Ajaj H. Ishakani \\ Department of Aquaculture, College of Fisheries, Junagadh Agricultural University, Veraval-362267 (Gujarat), \\ INDIA \\ *Corresponding author. E-mail: sumaraayaz@gmail.com \\ Received: January 22, 2015; Revised received: September 29, 2015; Accepted: October 30, 2015
}

\begin{abstract}
The growth and survival of Litopenaeus vannamei post larvae was measured in controlled different salinities condition 35ppt (T1), 40ppt (T2), 45ppt (T3) and 50ppt (T4) were maintained. Group of Shrimp post larvae (weight $0.032 \mathrm{~g} \pm 0.002$ ) were stocked at a density of 35 nos. /aquarium in above salinity ranges. Animals were fed with commercial feed ( $35 \%$ Crude Protein) @ $5 \%$ of body weight four times a day. The results indicate that higher SGR was observed in T2 $(1.99 \pm 0.08)$ followed by T1 $(1.75 \pm 0.07)$, T3 (1.54 \pm 0.06$)$ and T4 (1.49 \pm 0.17$)$. Highest survival $(100 \%)$ was recorded in T1 followed by T2 $(96.42 \%)$, T3 $(94.99 \%)$ and T4 $(74.21 \%)$. From the results of the present study it could be seen that higher salinity significantly reduced the growth and survival of $L$. vannamei but will also open study area of physiological adaption of animal at higher saline water in performance of organisms.
\end{abstract}

Keywords: Growth, Higher salinities, Litopenaeus vannamei, Specific growth rate, Survival

\section{INTRODUCTION}

Aquaculture is currently one of the fastest growing food production systems in the world. Aquaculture production of India was 50, 70, 851 tonnes by contributing about $8.29 \%$ of the total world fish production in 2011 (FAO, 2013). India has achieved considerable production increases in aquaculture, especially in the production of freshwater fishes and shrimps. The development of coastal aquaculture in India has been concentrated mainly on shrimps and some commercially important marine fishes (Anonymous, 2010).

In a comparison made in the production between $P$. monodon and L. vannamei it was observed that the estimated production of $\mathrm{P}$. monodon increased from 0.76 lakh tones during 2008-09 to 1.36 lakh tonnes during 2011-12 over a period of four years, L. vannamei production increased from 1,731 MT on 2009-10 to 80,717 MT during 2011-12 registering a remarkable growth within a period of three years. L. vannamei contributed 88.84 to the overall shrimp production of about 31 lakh tones in 2014 (Ramraj, 2014).

Currently, Pacific white shrimp is rapidly replacing the black tiger shrimp as the main farmed species in the country. The main reason for this change is that L. vannamei has a faster growth, higher stocking rate and yield, and incurs lower production costs than P. monodon. In shrimp aquaculture, growth and survival of the individuals are influenced by number of ecological factors, salinity being one of the most important of them. In India, majority of the coastal aquaculture farms have higher salinity problem. It has been demonstrated in some Gulf countries that L. vannamei can be cultured successfully at higher salinity (Abbas et al., 2010).Looking to this, studies on the effect of higher salinity on growth and survival of L. vannamei was proposed. However, increasing salinity beyond a particular level may lead to increase in production cost. Therefore, the aim of the present study was to find out the exact (optimum) level of salinity in L. vannamei to get higher growth and survival.

\section{MATERIALS AND METHODS}

L. vannamei post larvae were brought from shrimp hatchery, Kotda (20o 41' N, 70o 50') to the wet laboratory. The Post larvae were acclimatized in 500 liters capacity plastic tank. The experiment consisted of 4 treatments with four replica tanks per treatment. In this experiment four different treatments designated as $\mathrm{T} 1$, T2, T3 and T4 corresponds to salinities. In T135ppt salinity, in T2 40 ppt salinity, in T3 45 ppt salinity and T4 50 ppt salinity were maintained. The experiment was conducted adoption completely randomized design (CRD). The experiment was carried out in rectangular plastic aquariums of $2 \times 2 \times 1.5$ feet. The aquariums were scrubbed and cleaned with chlorinated water, flushed thoroughly, dried before use and arranged on stands in wet laboratory. The treatments were designed as follows:

$\mathrm{T} 1=$ water salinity $35 \mathrm{ppt}$ (Control),

$\mathrm{T} 2=$ water salinity $40 \mathrm{ppt}$,

$\mathrm{T} 3=$ water salinity $45 \mathrm{ppt}$ and

$\mathrm{T} 4=$ water salinity $50 \mathrm{ppt}$ 
Desired treatment salinities were prepared by mixing of treated seawater and by addition of brine solution (Helm and Bourne, 2004). Salinities were determined by refractometer (Atago Ltd, Japan) calibrated with distilled water. Aquariums were filled with 40 liters of filtered sea water.

Shrimp post larvae (weight $0.036 \mathrm{~g} \pm 0.002$ ) were stocked at a density of 35 nos./aquarium in all 16 aquarium tanks. Shrimp post larvae were fed with commercial shrimp feed at the rate of $5 \%$ of body weight four times a day during the culture period. During the first week, the shrimp post larvae were maintained on a combination of Artemia nauplii and commercial feed. Thereafter shrimp were fed with commercial feed four times daily at morning (6:00 a.m.), afternoon (12:00 p.m.), and evening (6:00 p.m.) and in night time (10:00 p.m.). Shrimp in each tank were appraised weekly and their feed ration was adjusted accordingly. Growth of shrimp post larvae was measured at week interval. All animals were collected from each tank and individual weight was measured. Mean weight of animals in each tank was calculated at week interval.

Water quality was maintained by regular replenishment of $20 \%$ of bottom water from each tank. Before morning feeding and evening feeding tanks were siphoned out by small tube to remove uneaten feed and waste. The $\mathrm{pH}$ and temperature were measured by $\mathrm{pH}$ meter (Hanna, Portugal) and mercury thermometer respectively. Salinities were determined by refractometer (Atago Ltd, Japan) calibrated with distilled water. Dissolved oxygen and alkalinity were measured using APHA (2005) methods. Survival, Feed conversion ratio (FCR) specific growth rate (SGR) (El- Sayed, 1999) and production were calculated as follows:

Mean weight increment $=$ Final average body Initial average body weight

$\mathrm{SGR}=[($ Loge W2 - Loge W1 $) / \mathrm{T} 2-\mathrm{T} 1] \times 100$
Where,

$\mathrm{T} 1$ and $\mathrm{T} 2$ are 0 and 63 th day of the experiment and $\mathrm{W} 2=$ weight of shrimp at time $\mathrm{T} 2$,

$\mathrm{W} 1=$ weight of shrimp at time $\mathrm{T} 1$

$\mathrm{FCR}=$ Feed intake $(\mathrm{g}) /$ Weight gain $(\mathrm{g})$

Survival $(\%)=$ (No. of shrimp survived after experiment/No. of shrimp stocked) x 100

Statistical design and analysis: One way Analysis of Variance 'ANOVA' tests (Snedecor and Cochran, 1968) was applied to check the significant difference among the treatments. The pairs of treatments that differed significantly were determined by one factor CRD design.

\section{RESULTS}

The present study observed that there was no significant effect of treatments on weight gain in initial three weeks, but from fourth week onwards significant $(\mathrm{P}<0.05)$ difference in weight gain was observed among treatments (Fig.1).

Higher SGR was observed in T2 treatment (1.99\%) followed by treatment T1 $(1.75 \%)$, T3 $(1.54 \%)$ and T4 (1.49\%).Statistical analysis showed that there is significant $(\mathrm{P}<0.05)$ difference among treatments (Table 1).It could be seen from the result of the present study that specific growth rate reduced with increase salinity.

Among the salinity tested, the best FCR $(1.98 \pm 0.02)$ was recorded in treatment T2 followed by T1 $(2.17 \pm$ $0.04), \mathrm{T} 3(2.1 \pm 0.02)$ and $\mathrm{T} 4(2.14 \pm 0.06)$. All the treatments significantly differed from each other $(\mathrm{p}<0.05)$.

Among the salinity tested, the highest survival (100\%) was recorded in treatment $\mathrm{T} 1$ followed by $\mathrm{T} 2$ $(96.42 \%)$, T3 (94.99\%) and T4 (74.21\%). The lowest percentage survival was observed for treatment $\mathrm{T} 4$ $(74.21 \%)$.

Table 1. Growth parameter of L. vannamei in different treatment during study period.

\begin{tabular}{|c|c|c|c|c|}
\hline \multirow{2}{*}{ Parameter } & \multicolumn{4}{|c|}{ Treatments } \\
\hline & T1 (35ppt) & T2 (40 ppt) & T3 (45 ppt) & T4 (50 ppt) \\
\hline Initial weight (g) & $0.034 \pm 0.002^{\mathrm{d}}$ & $0.023 \pm 0.002^{\mathrm{e}}$ & $0.022 \pm 0.002^{\mathrm{d}}$ & $0.032 \pm 0.001^{\mathrm{e}}$ \\
\hline Final weight $(\mathrm{g})$ & $1.152 \pm 0.048^{\mathrm{b}}$ & $1.293 \pm 0.11^{\mathrm{c}}$ & $1.010 \pm 0.040^{\mathrm{c}}$ & $0.982 \pm 0.054^{\mathrm{d}}$ \\
\hline Live weight gain $(\mathrm{g})$ & $1.118 \pm 0.79^{\mathrm{a}}$ & $1.269 \pm 0.89^{b}$ & $0.988 \pm 0.70^{\mathrm{b}}$ & $0.950 \pm 0.68^{b}$ \\
\hline Daily weight gain $(\mathrm{g})$ & $0.017 \pm 0.005^{\mathrm{c}}$ & $0.020 \pm 0.07^{\mathrm{d}}$ & $0.015 \pm 0.04^{\mathrm{c}}$ & $0.015 \pm 0.04^{\mathrm{cd}}$ \\
\hline Survival (\%) & $100 \pm 00$ & $96.42 \pm 1.33^{\mathrm{a}}$ & $94.99 \pm 1.62^{\mathrm{a}}$ & $74.21 \pm 8.27^{\mathrm{a}}$ \\
\hline Specific growth rate (SGR) (\%) & $1.75 \pm 0.07^{\mathrm{bc}}$ & $1.99 \pm 0.08^{\mathrm{d}}$ & $1.54 \pm 0.067^{\mathrm{b}}$ & $1.49 \pm 0.17^{\mathrm{c}}$ \\
\hline Feed conversion ratio (FCR) & $2.17 \pm 0.04^{\mathrm{b}}$ & $1.98 \pm 0.02^{\mathrm{e}}$ & $2.10 \pm 0.02^{\mathrm{d}}$ & $2.14 \pm 0.06^{\mathrm{d}}$ \\
\hline
\end{tabular}

Mean \pm SD of four replicates; Different superscript indicates significantly different from each other $(\mathrm{P}<0.05)$.

Table 2. Water quality parameter during study period.

\begin{tabular}{lllll}
\hline Parameter & T1 & T2 & T3 & T4 \\
\hline $\mathrm{pH}$ & $7.94 \pm 0.11$ & $7.96 \pm 0.06$ & $7.99 \pm 0.04$ & $7.97 \pm 0.06$ \\
Dissolve Oxygen $(\mathrm{ppm})$ & $5.46 \pm 0.37$ & $5.45 \pm 0.50$ & $5.43 \pm 0.34$ & $5.42 \pm 0.35$ \\
Temperature $\left({ }^{0} \mathrm{C}\right)$ & $21.93 \pm 1.05$ & $22.04 \pm 1.05$ & $21.97 \pm 0.99$ & $22.02 \pm 0.90$ \\
Alkalinity $(\mathrm{ppm})$ & $107 \pm 0.99$ & $110 \pm 1.1$ & $106 \pm 1.02$ & $104 \pm 0.97$ \\
\hline
\end{tabular}

Mean \pm SD of four replicates 
Statistical analysis showed that there was significant difference in survival rate among all the treatments at each week interval $(\mathrm{p}>0.05)$.

Water parameter: Constant aeration was provided in all the tanks to keep the dissolve oxygen level above 5 ppm. Water quality parameters (Temperature $22.04 \pm$ $1.05^{\circ} \mathrm{C}$ to $22.02 \pm 0.90^{\circ} \mathrm{C} ; \mathrm{pH} 7.94 \pm 0.11$ to $7.99 \pm$ 0.04 ; dissolved oxygen $5.43 \pm 0.34$ to $5.46 \pm 0.37 \mathrm{ppm}$ and Alkalinity $104 \pm 0.97$ to $107 \pm 0.99 \mathrm{ppm}$ ) were maintained within the optimum range by regular water exchange (Table no. 2).

\section{DISCUSSION}

Effect of higher salinities on growth (g) of $L$. vannamei: Based on mean weight calculated at the end of experiment higher growth rate was observed at 40 ppt salinity and lower growth was observed at $50 \mathrm{ppt}$ (Table 1). Higher weight gain was observed in $35 \mathrm{ppt}$ and 40 ppt salinity than in 45 and 50 ppt salinity.

Similar to Rizk et al. (2002) reported that P. kerathurus post larvae the optimum salinity range for growth of $P$. japonicus was $30 \mathrm{ppt}$ and in our study higher weight gain was observed in $40 \mathrm{ppt}$ salinity. In addition Zhu et al. (2004) studied the effect of $\mathrm{Na} / \mathrm{K}$ ratio on growth of L. vannamei juveniles, and stated that at higher salinities the rate of $\mathrm{Na}$ increased and affected the growth. This result is in agreement with the known fact that at lower salinity higher growth rate is observed (Menz and Blake, 1980; Pante, 1990; Bray et al., 1994; Somochaet et al., 1998; and McGraw et al., 2002).

Menz and Blake (1980) and Bray et al. (1994) reported that the L. vannamei is a euryhaline species that can tolerate a wide range of salinities (0.5-45 gL-1). In addition Mair, (1980); Cawthorne et al. (1983); Kumulu and Jones, (1995); Rosas et al. (1999) and Tsuzuki et al. (2000) found that the age range for tolerance to widely fluctuating salinity levels for most penaeid PL has been reported in between PL10 and PL40. According to this reference $L$. vannamei grow better in hyper saline water. Similar Bray et al., 1994 reported that $L$. vannamei grow better in salinities below the isosmotic point. The different optimum salinities for growth in different species generally correspond to the differences in their osmotic capacities. Species with higher hyper-OC grow better in the lower salinities, whereas species with lower hyper-OC grows better in the highest salinities. The results obtained in our work provide evidence that $L$. vannamei higher growth increment was in $40 \mathrm{ppt}$

Effect of higher salinities on survival of $\boldsymbol{L}$. vannamei : The results of the present study indicate that the survival rate reduced with increase in salinities. This is in agreement with the result obtained by Palafox et al. (1997) and Perez - Velazquez et al. (2007). Mcgraw et al. (2002) reported that the longer salinities adjustment period could also result in better survival rate. Chen et al. (1995) studied the survival,

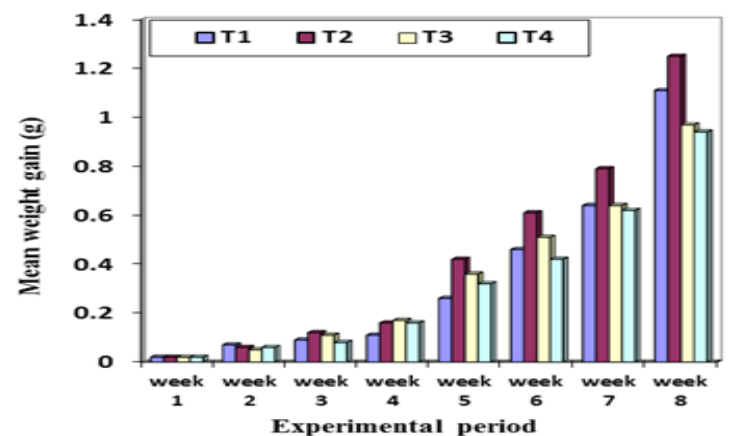

Fig. 1. Mean weight gain (g) of L. vannamei in different treatments during study period.

growth and osmolality of the haemolymph and the water content in the tissues of Fenneropenaeus chinensis juveniles, concluding that the osmolality of the haemolymph increased with an increase in salinity, and decreased with an increase in temperature

Most penaeid shrimps are known to be euryhaline species growing in a wide range of salinities, at least during their nursery stages. In the current work, the animals had consistently better survival, greater weight gain at $35 \mathrm{ppt}$ and $40 \mathrm{ppt}$ than at higher salinities, indicating that their optimal culture salinity $40 \mathrm{ppt}$. Salinity optima for the larval culture of the same species inhabiting the north-eastern Mediterranean were also reported to be between 30 and $35 \mathrm{ppt}$ (Kumlu et al., 1999; Kumlu and Eroldogan, 2000). In a study by Harpaz and Karplus (1991), carried out in Israel, 40-day-old PL of the same species had highest survival rate at $36 \mathrm{ppt}$ and slow growth and low survival at $9 \mathrm{ppt}$.

\section{Conclusion}

Based on the results obtained from the present study conducted, it was concluded that higher growth increment in treatment 2(40 ppt) and highest survival in treatment $1(35 \mathrm{ppt})$ in Litopenaeus vannamei can be obtained. Therefore on the basis of the result it is revealed that the treatment 2 i.e. 40 ppt salinity is better for weight gain and 35 ppt salinity is better for survival of L. vannamei. It may also be concluded from the present study that higher salinity beyond 40 ppt significantly reduces growth and survival in $L$. vannamei. Also the food conversion ratio, specific growth rate and percentage weight gain were found very good in 40 ppt salinity (T2).

\section{REFERENCES}

Abbas, M.E., Ramazani, F. and Mohammad, M. (2010). Introduction of $L$. vannamei to shrimp industry of Iran. Final report of research project.I .F.R.O. 42P.

Anonymous (2010). Annual report central institue of brackish water aquaculture, Chennai. pp. 1-190, retrieved from http://ciba.nic.in.

Anonymous (2012). Annual report coastal aquaculture authority Chennai. pp. 112-113, retrieved from http:// caa.nic.in. 
APHA (2005). Standard methods for the examination of water and waste water. 21 st edition.

Bray,W.A.,Lawrence, A.L. and Leung- Trujillo, J.R. (1994). The effect of salinity on growth and survival of Penaeus monodon, with observations on the interaction of IHHN virus and salinity. Aquaculture, 122:133-146.

Cawthorn, D.F., Beard,T., Davenport, J. and Wickins, J.F. (1983). Responses of juvenile Peneaus monodon Fabriciusto natural and artificial sea water of low salinity.Aquaculture,32:65-174.

Chen, J.C., Lin, M.N., Ting, Y.Y. and Lin, J.N. (1995). Survival, haemolymph osmolality and tissue water of Penaeus chinensis juveniles acclimated to different salinity and temperature levels. Comp. Biochem. Physiol, 110: 253-258.

El-Sayed, A.F.M. (1999). Alternative dietary protein sources for farmed tilapia (Oreochromis spp.).Aquaculture, 179:149-168.

FAO (2013).Fisheries Statistics.food and agricultural organization, Rome, Italy. retrieved from http://www.fao.org.

Harpaz, S. and Karplus, I. (1991). Effect of salinity on growth and survival of juvenile Penaeus semisulcatus reared in the laboratory. Israeli $J$. AquacultureBamidgeh, 43:156-163.

Helm, M.M. and Bourne,N.(2004). Hatchery culture of bivalves: A practical manual. FAO fisheries technical paper,471:31-129.

Kumlu, M. and Eroldogan, O.T. (2000). Effects of temperature and substrate on growth and survival of Penaeus semisulcatus post larvae. Turk. J. Zool,24:337-341.

Kumlu, M., Eroldogan, O.T. and Aktas, M. (1999). The effects of salinity on larval growth, survival and development of Penaeus semisulcatus (Decapoda: Penaeidae). Israeli J. Aquaculture Bamidgeh, 51:114-121.

Kumulu, M. and Jones, D.A. (1995).Salinity tolerance of hatchery-reared post larvae of Penaeus indicus. Milne Edwards originating from India. Aquaculture, 130: 287-296.

Mair, M.D.J. (1980).Salinity and water - type preferences of four species of post larval shrimp (Penaeus) from west Mexico. Journal of Experimental Marine Biology and Ecology, 45(1):69-82.

McGraw, J.W., Davis, D.A., Teichert-Coddington, D. and Rouse, D.B. (2002). Acclimation of Litopenaeus vannamei postlarvae to low salinity: influence of age, salinity endpoint and rate of salinity reduction. $J$. World Aquac. Soc,33:78-84.
Menz, A. and Blake, B.F. (1980). Experiments on the growth of Penaeus vannamei Boone. Journal of Experimental Marine Biology and Ecology, 48:99-111.

Palafox,J.P., Carlos,A.M. and Lindsay,G.R. (1997). The Effect of salinity and temperature on the growth and survival rates of juvenile White shrimp Penaeus vannamei, Boone, 1931. Aquaculture, 157:107-115.

Pante,M.J.R. (1990). Influence of environmental stress on the heritability of molting frequency and growth rate of the penaeid shrimp, Penaeus vannamei. University of Houston-Clear lake, Houston, TX, USA, M.Sc. Thesis.

Parado-Estepa, F.D., Quinitio, E.T. and Borlongan, E.L. (1996). Prawn hatchery operations (Rev. ed.). Tigbauan, Iloilo, Philippines: Aquaculture Department, Southeast Asian Fisheries Development Center.

Perez-Velazquez, M., Gonzalez-Felix, L.M., JaimesBustamente, F., Martinez-Cordova and TrujilloVillalba, R.L. (2007).Investigation of the Effects of Salinity and Dietary Protein Level on Growth and Survival of Pacific White Shrimp, Litopenaeus vannamei. Journal of the world aquaculture society, 38(4).

Ramraj,D. (2014). Review of Shrimp Hatcheries and Farm productions Society of Aquaculture Professional pp:2-4.

Rizk, E.T., Mona, M.H., Abdel Razek,F.A., Abdel Rahman,S.H. and Moussa, R.M.(2002). Observations on growth and survival of Penaeus japonicus (Bate) post larvae acclimated to low-salinity. Proc. I .C.B.S, 2 (2):167-183.

Rosas, C., Ocampo,L.,Gaxiola,G.,Sanchez,A. and Soto,L.A. (1999). Effect of salinity on survival, growth, and oxygen consumption of post larvae (PL10-PL21) of Litopenaeus setiferus. J. Crustac. Biol,19:244-251.

Samocha, T.M., Guajardo,H., Lawrence, A.L., Castille, F.L., Speed, M. and Mckee, D.A. (1998). A simple stress test for Penaeus vannamei post larvae. Aquaculture, 165:233 -242 .

Snedecor,G.W.and Cochran,W.G.(1968). Statistical methods the lowa state university press, lowa, U.S.A. pp1-435.

Tsuzuki, M.Y., Cavalla, R.O. and Bianchini,A. (2000). The effects of temperature, age, and acclimation to salinity on the survival of Farfantepenaeus paulensis post larvae. J. World. Aquac.Soc,3:459-468.

Zhu, C., Dong, S., Wang, F. and Huang, G. (2004). Effect of Na/K ratio in seawater on growth and energy budget of juvenile Litopenaeus vannamei. Aquaculture, 234:485-496. 